\title{
Asymmetrical Assumption: Why Lutheran christology does not lead to kenoticism or divine passibility
}

\author{
Stephen R. Holmes
}

University of St Andrews

'...the most relevant and beautiful problems in dogmatics begin at the very point where the fable of

"unprofitable scholasticism" and the slogan about the "Greek thinking of the Fathers" persuade us we ought to stop.' 1

\begin{abstract}
:
It has been commonplace for over a century to argue that the distinctively Lutheran form of the communicatio idiomatum leads naturally to kenotic christology, divine passibility, or both. This argument has been generally accepted as a historical claim; it has also been advanced repeatedly as a criticism of 'classical theism' in the literature, and it has featured significantly in almost all recent defences of divine passibility. I argue that it does not work: the Lutheran scholastics had ample resources drawn from nothing more than ecumenical Trinitarian and christological dogma to defend their denial of the genus tapeinoticum. I argue further that this defence, if right, undermines a remarkably wide series of proposals in contemporary systematic theology.
\end{abstract}

\section{Introduction}

For well over a century, theologians have been arguing that the distinctively Lutheran form of the communicatio idiomatum, which accepts the genus maiestaticum, leads naturally to kenotic christology, divine passibility, or both. Indeed, it is not hard to find suggestions that the move is so obvious that the interesting question is why the scholastic Lutheran theologians could not see it, a question generally answered by lamenting their captivity to alien hellenistic conceptions of deity (recently termed 'classical theism'). In this essay I argue that this long-standing historical interpretation is wrong. The paper falls into three sections, after some definitions of key technical terms: a demonstration that the position under consideration has been so normal as to be generally assumed without argument since about 1860; a close reading of sixteenth- and seventeenth-century Lutheran dogmaticians to show that it is simply wrong; and a consideration of the significance of this discovery.

\section{A lasting systematic connection}

The communicatio idiomatum (communication of attributes/properties) is a standard theme of scholastic christology, common to Orthodox, Roman Catholic, Reformed, and Lutheran dogmaticians. The ecumenical doctrine affirms that the proper attributes of both divine and human natures are given ('communicated') to the one person of the incarnate Son, who is thus properly named as both divine and human, both omnipresent and local, both eternal and born of the Virgin. As a result of the Eucharistic controversies which split the early Reformation, a debate arose concerning this doctrine: Zwingli, and the Reformed tradition following him, argued that, since body and blood were properties of the human nature, they were necessarily local, and so could not be simultaneously present on many altars; the Lutheran response was to suggest that the proper attributes of the divine nature

\footnotetext{
${ }^{1}$ Karl Barth, C.D. I/1, p. xiv.
} 
were communicated, not just to the person, but to the human nature, and so that the human nature could transcend spatial restrictions, and be present on many altars simultaneously.

This debate led to extensive scholastic analysis of the communicatio idiomatum. Three genera of the communicatio were identified: the genus idiomaticum, which names the attribution of the properties of both natures to the person; the genus apostelesmaticum, which names the perfect cooperation of the two natures, with all their properties, in the work of the Mediator; and the genus maiestaticum, which names the participation in the majesty, and so the properties, of the divine nature by the human nature. The former two were affirmed ecumenically; the last was affirmed by the Lutherans but denied by the Reformed, and so was the crux of debate. 'Lutheran christology' in all that follows in this essay means simply a scholastic christology that affirms the genus maiestaticum. For completeness, we need to note the logical possibility of a fourth genus, the genus tapeinoticum, which would, if affirmed, name the participation in the weakness and limitation of human nature by the divine nature. In the scholastic period, this existed only as a polemical invention of the Reformed, asking why the Lutherans affirmed communication from one nature to the other in one direction, but not in the other. ${ }^{2}$

With these definitions and distinctions in place, the argument connecting Lutheran christology, kenosis, and divine passibility is easy to sketch: the genus maiestaticum affirms the communication of divine properties to the human nature; but (as the Reformed insisted) Chalcedonian christology seems to assert a basic symmetry between the two natures, suggesting that, without good reason to think otherwise, what happens from nature to nature should be symmetrical. Therefore, if the genus maiestaticum is affirmed, so should be the genus tapeinoticum, the communication of the properties of the human nature to the divine nature. It should, therefore, be asserted that the divine nature becomes mutable (allowing an account of kenosis) and passible, because mutability and passibility are proper attributes of the human nature.

In 1856, Isaak Dorner already saw Thomasius's development of kenotic christology as a result of precisely this move, blaming (rather remarkably) the first edition of his own Entwicklungsgeschichte der Lehre von der Person Christi. He cites himself as saying 'The fault of the Lutheran Christology lies ultimately in the incomplete carrying out of the "Communicatio idiomatum," or in the circumstance that the communication is not represented as actually reciprocal, that the finite determinations are not really taken up into the divine nature.' ${ }^{3}$ Dorner suggests, and the evidence bears out, that Thomasius's Beiträge zur kirchlichen Christologie $e^{4}$ explicitly picks up this hint and develops it in ways that

\footnotetext{
${ }^{2}$ See, e.g., Francisco Turretino, Institutio Theologiae Elencticae (3 tom.) (Edinburgh: John D. Lowe, 1847) tom. 2; XIII.8.xii (p. 286 of edition cited): 'Quia si propter Unionem proprietates divinae communicatae sunt Carni, Ergo vicissim proprietates Carnis debuerunt communicari Logoi quia unio est reciproca...' The second section of this essay will be mainly concerned with Lutheran responses to this argument.

${ }^{3}$ Isaak A. Dorner (tr. D.W. Simon), History of the Development of the Doctrine of the Person of Christ ii.2 (Edinburgh: T\&T Clark, 1866), p. 427.

${ }^{4}$ D.G. Thomasius, Beiträge zur kirchlichen Christologie (Addend auss der ZPK) (Erlangen: Theodor Bläsing, 1845). (This is a republication with addenda of the two original articles.) See pp. 97-104 for the development of the theory along the lines Dorner sketched out, and p. 63 for an explicit reference to the relevant part of Dorner's first edition. On Thomasius's christology see David R. Law, 'Le kenotisme luthérien et anglican: les
} 
Dorner came to view as 'unripe and untenable'. 5 The criticism, however, is that it involves a doctrine of God that is not ethical. Dorner, that is, criticises Thomasius for a failure to follow (what Dorner sees as) a primary condition placed on dogmatics postSchleiermacher, ${ }^{6}$ not for misreading the Lutheran tradition; he apparently continues to believe that kenoticism is a valid scholastic development of Luther's ideas. Indeed, the reader of his account of the various debates between the Schwabians and Chemnitz, ${ }^{7}$ and then between the theologians of Giessen and those of Tübingen, ${ }^{8}$ might well be left thinking that he believes it to be the only valid development, although untenable in the light of the Schleiermacher's re-orientation of dogmatics. ${ }^{9}$

Thomasius himself was convinced that the heart of his work, developing moves already underway at Erlagen when he arrived, was a renewal of classical Lutheranism. His 1848 work on the confessional inheritance of Lutheranism makes this very clear. ${ }^{10}$ Historians of kenotic Christology have since repeatedly made the same link, right down to the present decade. ${ }^{11}$ It seems that there has been broad agreement that kenotic Christology is a natural development of the Lutheran doctrine of the communicatio idiomatum. Of course, saying this raises the question of why there was no (or perhaps little) true kenoticism

christologies de Gottfried Thomasius et Frank Weston' Études Theologiques et Religieuses 89 (2014), pp. 313340 .

${ }^{5}$ Dorner, History, ii.2 p, 427. This rather remarkable mea culpa appears not to have been widely noticed in the literature.

${ }^{6}$ See I.A. Dorner (tr. Alfred Cave), A System of Christian Doctrine vol. 1 (Edinburgh: T\&T Clark, 1880), pp. 412ff., and I.A. Dorner (tr. R.R. Williams \& Claude Welch), Divine Immutability: A critical reconsideration (Minneapolis: Fortress, 1994). For a fine account of this theme in Dorner, see Jonathan Norgate, Isaak A. Dorner: The Triune God and the Gospel of Salvation (London: T\&T Clark, 2009), pp. 10-52. Other useful secondary treatments include: Robert R. Williams, 'I.A. Dorner: The ethical immutability of God' JAAR 54 (1986), pp. 721-38; Robert Sherman, 'Isaak August Dorner on Divine Immutability: A missing link between Schleiermacher and Barth', J. Rel. 77 (1997), pp. 380-401. For two different genealogies that downplay Schleiermacher but nevertheless do not invalidate my point about this being a nineteenth-century concern, see Robert E. Brown, 'Schelling and Dorner on Divine Immutability' JAAR 52 (1985), pp. 237-49, and Piotr J. Malysz, 'Hegel's Conception of God and its Application by Isaak Dorner to the Problem of Divine Immutability' Pro Ecc. 15 (2006), pp. 448-71.

${ }^{7}$ Dorner, History, pp. 177-192; 198-208.

${ }^{8}$ Dorner, History, pp. 281-300.

${ }^{9}$ David R. Law, 'Luther's Legacy and the Origins of Kenotic Christology' BJRL 93 (2017), pp. 41-68, suggests Sartorius, rather than Dorner, as the key influence for Thomasius, relying on a footnote in which the latter highlights the work of the former. As Law notes, Breidert finds the identification of Sartorius as an early kenoticist implausible (M. Breidert, Die kenotische Christologie des 19. Jahrhunderts (Gütersloh: Gütersloher Verlagshaus Gerd Mohn, 1977), p. 39, which is cited in Law, 'Luther's Legacy...' n.49 on p. 65). It is of course possible that Thomasius found inspiration in a misreading of Sartorius, whose work (on Law's telling) is not always completely consistent. All that said, Law's essay begins and ends with assertions that kenotic Christology finds its origins in Luther, so he is not opposed to the historical line I am developing here, regardless of any difference over influences on Thomasius.

10 Gottfried Thomasius, Das Bekenntnis der evangelisch-lutherischen Kirche in der Konsequenz seines Prinzips (Nuremberg: A. Recknagel, 1848).

11 To take only a sample: Francis J. Hall, The Kenotic Theory: Considered with particular reference to its Anglican forms and arguments (London: Longmans, Green, and co., 1898), pp. 13-15; Oscar Bensow, Die Lehre von der Kenose (Leipzig: A. Deichert, 1903), pp. 15-28 and 42-52; John Stewart Lawton, Conflict in Christology: A Study of British and American Christology from 1889-1914 (London: SPCK, 1947), p. 119; Donald G. Dawe, 'A Fresh Look at the Kenotic Christologies' SJT 15 (1962), pp. 337-349, p. 341; M. Breidert, Kenotische Christologie, pp. 19-23; David Brown, Divine Humanity: Kenosis and the construction of a Christian theology (Waco, TX: Baylor University Press, 2011), pp. 27-29; David R. Law, 'Kenotic Christology' in David Fergusson (ed.), The Blackwell Companion to Nineteenth-Century Theology (Oxford: Wiley-Blackwell, 2010), pp. 251-279, pp. 253-255. 
before the nineteenth century; ${ }^{12}$ the answer would seem to be Dorner's ethical turn, already referenced above. If the essence of divine majesty is understood as omnipotence, omniscience, and omnipresence, then a kenotic theory that involves the divine Logos laying down these attributes is difficult to imagine; 13 if however we accept Dorner's reorientation of the doctrine of divine perfection, such that 'moral' attributes such as love or holiness are of the essence of divine majesty, then it is far easier to develop a kenotic theory. This distinction was used extensively by kenoticists from Thomasius to Forsyth (and beyond). ${ }^{14}$

The connection between Lutheran christology and kenoticism seems, then, well established virtually from the beginnings of serious kenotic theories in the middle of the nineteenth century. Divine passibility becomes a common idea later still, although it is linked explicitly to Lutheran christology even before its recent popularity. There is a debate over divine passibility in England culminating in two significant works from the 1920 s, 15 but the theme only becomes pervasive in systematic theology in the second half of the twentieth century - although it does then become pervasive: in the 1980s, writers on both sides of the Atlantic could suggest that it had become so common as to be a 'new orthodoxy'. ${ }^{16}$ If Moltmann's Crucified God is the great work announcing this new movement, its genealogy runs from a particular reading of Barth, mediated by Jüngel, through Jenson, Moltmann, and Pannenberg, to (inter alia) Fiddes.

\footnotetext{
${ }^{12}$ Discussing Chemnitz and his followers, Dorner comments, tantalisingly, that they taught '...[t]he communication of the natures to each other; in this case, the communication to the divine nature was usually omitted...' (Dorner, History, ii.2, p. 287; my emphasis). He gives no reference, and I have not been able to discover to whom he might have been referring, but the qualification suggests that he was aware of at least one early modern Lutheran who proposed the genus tapeinoticum. Welch raises the question as to why this issue did not become pressing earlier, and suggests that the nineteenth-century focus on Christology is sufficient answer; I am not sure that this is adequate, as there had been previous moments of extensive focus on Christology within Lutheran dogmatics, not least the Schwabian debates with Chemnitz and the GiessenTübingen debate already mentioned. Welch, God and Incarnation... pp. 6-9.

${ }^{13}$ The seventeenth-century Lutheran theologians (on both the Tübingen and Giessen sides) had argued for a kenosis of the logos ensarkos, which generally amounted to the voluntary hiding (Tübingen) or shedding (Giessen; again, the word 'kenosis' was used) of the majestic attributes conferred on the human nature by the human nature. As Mark Elliott puts it: '[b]oth sides were in agreement that the subjectum quo of kenosis is the Person, but the subjectum quod is the exalted humanity of the incarnation... Seventeenth-century Lutherans would hardly have thought that the Logos as such could lose any of his divine properties.' M.W. Elliott, 'Christology in the Seventeenth Century', in Francesca A. Murphy (ed.), The Oxford Handbook of Christology (Oxford: OUP, 2015), pp. 297-314, p. 304.

${ }^{14}$ For this in Thomasius himself, see Gottfried Thomasius, Christi Person und Werk: Darstellung der evangelischlutherischen Dogmatik... (3 Bd) (Erlangen: Blasig, 1856-1863), i.20-208.

${ }^{15}$ J.K. Mozley, The Impassibility of God: A Survey of Christian Thought (Cambridge: Cambridge University Press, 1926) and Bertrand R. Brasnett, The Suffering of the Impassible God (London: SPCK, 1928). Alfred North Whitehead also argued for divine passibility around this time (see, e.g., the famous description of God as a 'fellow sufferer who understands' Whitehead, Process and Reality: An Essay in Reality Corrected Edition (New York: Free Press, 1978 [1929]), p. 351). Whitehead made no reference to Luther, and so is not very relevant for my ongoing argument; his entire programme, however, depended on suggesting a Platonic infection of Christian theology, and so he does exemplify at least one point of my reconstruction.

16 Ronald Goetz, 'The Suffering God: The rise of a new orthodoxy' Christian Century 103 (1986), p. 385, uses this phrase; Paul S. Fiddes, The Creative Suffering of God (Oxford: Clarendon Press, 1988) comments similarly of 'academic circles' that 'the idea that God suffers hardly needs to be argued for any longer.' (p. 1).
} 
In the earlier English debate, Lutheran christology was offered as the most straightforward account of divine passibility in the tradition. Mozley cites two (fairly occasional) works of Luther - a sermon, and the Table Talk - which both contain assertions of divine passibility based on a simple symmetrical account of the communication between divine and human natures. ${ }^{17}$ He then turns to Gerhard for a more systematic treatment, 18 and finds a clear statement that the Logos truly suffered and died in the human nature, on the basis of which Gerhard claimed that we can say 'God suffered' just as straightforwardly as we can say 'God is man'. Mozley appears to think that this is significant, but it is of course unremarkable according to the conciliar tradition, mirroring the 'theopaschite' formula declared orthodox at Constantinople II in 553, 'unus de trinitate carne passus est.'19

There is no revolutionary account of divine passibility in Gerhard, then; what of Luther? Lugioyo's warnings about the impossibility of systematising Luther's christology are significant, ${ }^{20}$ but there seems to be general agreement amongst more recent commentators that Mozley's reading is correct: Lugioyo himself, Ngien, Jenson, and Weinandy all read Luther in the same way, ${ }^{21}$ citing texts far more central to the corpus. ${ }^{22}$ Dorner had read Luther like this also. ${ }^{23}$ It is certainly possible to find texts in Luther that seem to claim, more traditionally, that the incarnate Logos suffers only in his human nature, whilst remaining impassible in his divine nature, ${ }^{24}$ but the overall thrust of Luther's christology seems to involve a symmetrical transference of properties between the natures, and so, necessarily, a passible deity. Following Congar, Weinandy suggests that this is because of a certain lack of interest in the metaphysical content of the word 'person', which is reduced to merely the product of the union of the two natures. ${ }^{25}$ Zachhuber is less willing to accept Luther as a forerunner of divine passibility, arguing that the passages speaking of God suffering should be read as deliberately shocking embraces of paradox designed to make explicitly Christological points. ${ }^{26}$ That said, he does make a similar point to

\footnotetext{
17 Mozley, Impassibility, pp. 121-123.

18 Mozley, Impassibility, pp. 123-125.

${ }^{19}$ On the theopaschites and the origin of the formula, see J.A. McGuckin, "The "Theopaschite Confession" (Text and Historical Context): A study in the Cyrillic re-interpretation of Chalcedon' JEH 35 (1984), pp. 239255.

${ }^{20}$ Brian Lugioyo, 'Martin Luther's Eucharistic Christology' in Francesca A. Murphy (ed.), The Oxford Handbook of Christology, (Oxford: OUP, 2015), pp. 267-283. As Congar points out, one of the particular problems is that, in the German works, Luther uses 'Wesen' to mean both 'nature' and 'person', introducing inevitable ambiguity and confusion. Yves M.-J. Congar, 'Regards et réflexions sur la christologie de Luther' in Aloys Grillmeier und Heinrich Bacht (hrsg.), Das Konzil von Chalkedon: Geschichte und Gegenwart Bd III (Würzburg: Echter-Verlag Wuurzburg, 1959), pp. 457-486, p. 482.

${ }^{21}$ Lugioyo, 'Martin Luther's Eucharistic Christology', p. 278; Dennis Ngien, 'Chalcedonian Christology and Beyond: Luther's Understanding of the Communicatio Idiomatum' HeyJ XLV (2004), pp. 54-68; idem. The Suffering of God According to Martin Luther's 'Theologia Crucis' (Vancouver: Regent College Publishing, 2005); Robert W. Jenson, 'Christ in the Trinity: The Communicatio Idiomatum' in Stephen R. Holmes and Murray A. Rae (eds), The Person of Christ (London: T\&T Clark International, 2005), pp. 61-69, p. 66; Thomas G.

Weinandy, Does God Change? The Word's Becoming in the Incarnation (Still River, MA: St Bede's Publications, 1985), pp.104-108.

22 See particularly Ngien's reference to the Schwabach Articles; Ngien, 'Chalcedonian Christology...', p. 56.

${ }^{23}$ Dorner, History, ii.2, pp.281-307.

24 See, e.g., the 1528 Confession Concerning Christ's Supper.

25 Weinandy, Does God Change?, pp. 103-104; cf. Congar, 'Regards et Réflexions...' pp. 477-478.

${ }^{26}$ Johannes Zachhuber, Luther's Christological Legacy: Christocentrism and the Chalcedonian Tradition (The Père Marquette Lecture in Theology 2017) (Milwaukee, WI: Marquette University Press, 2017), p. 47.
} 
Weinandy and Congar, suggesting that Luther is rather happy to elide the distinction between 'nature' and 'person' in his Christological formulae. ${ }^{27}$

Thomasius suggests in his account of kenosis that a symmetry in the communicatio idiomatum led inevitably to divine passibility, and that this was the tendency, at least, of Lutheran christology from Luther onwards. ${ }^{28} \mathrm{He}$ offers no real evidence for this claim, and it is probably best read as a theoretical account of what he believes the doctrine would have looked like if dogmaticians had been consistent, rather than a historical account of what was actually taught. ${ }^{29}$

Mozley goes on to note that no significant dogmatician or historian of dogma treated the question through the nineteenth century or in the early part of the twentieth. ${ }^{30} \mathrm{He}$ expresses surprise that Ritschl and von Harnack had nothing to say, given that impassibility 'could be represented as a piece of Greek metaphysics.' ${ }^{1} 1$ Instead, the challenges to the doctrine have come two sources: from what he terms 'metaphysics', by which he seems particularly to mean both, first, a focus on the personality of the deity, similar to Dorner's ethical turn, and a broader personalistic philosophy; and, second, what he terms 'natural science', by which he seems to mean a panentheistic move in which God suffers all that any creature suffers. ${ }^{32}$

Nearly a century on, not only many of the names, but also many of the concepts, Mozley found to be important have passed into historical irrelevance; however, his identification of a 'metaphysical' move, and his expressed surprise at Ritschl's silence, continue to resonate in more recent discussion. Both turn on a sense that the foundational conception of the being of God received in the theological tradition was somehow wrong, or at best unbalanced. He concludes the book posing six questions, the first of which 'concerns the nature of God as the Absolute ... and, at the same time, as personal.' 33 A merely absolute deity might be impassible; a deity possessed of personality must be passible in some sense. Dorner's ethical turn made the question of divine passibility urgent.

At the start of the later twentieth-century development stands a parallel dissatisfaction with an inherited doctrine of God. Two (related) early discussions of Feuerbach by Barth (which coincidentally are almost contemporaneous with Mozley's book) offer a way in to this question. ${ }^{34}$ Barth reads Feuerbach's critique of theology remarkably positively: in claiming that the account of God offered by the (Schleiermachian) theologians of his day

\footnotetext{
27 Zachhuber, Luther's Christological Legacy..., pp. 100-101.

28 Thomasius, Beiträge, pp. 31ff.

${ }^{29}$ Welch suggests he sees it as 'the intention and direction of the Lutheran Christological development'. God and Incarnation, p. 27.

${ }^{30}$ He references many authors who did address the issue in the six decades before he wrote; the only two whose memory has generally survived are Horace Bushnell and William Temple. Mozley, Impassibility, pp. 140-166.

31 Mozley, Impassibility, p. 129.

32 Mozley, Impassibility, pp. 130-139.

33 Mozley, Impassibility, p. 177.

34 'Ludwig Feuerbach'(identified as an extract from lectures given in 1920) in Karl Barth (tr. Louise Pettibone Smith), Theology and Church: Selected Shorter Writings 1920-1928 (London: SCM Press, 1962), pp.217-237, and Barth (tr. Brian Cozens and John Bowden), Protestant Theology in the Nineteenth Century: Its background and history (Grand Rapids: Eerdmans, 2002), pp. 520-526.
} 
was nothing but an account of projected human desires, Feuerbach was simply right, and was doing a great service to theology, demonstrating the inadequacy and bankruptcy of a theological method that was genuinely without validity. ${ }^{35}$ Christian theology is not projection, Barth believes, but reception of revelation, and therefore impervious to Feuerbach's critique.

Now, this might be right or wrong, but it offers a significant conceptual distinction, which may be employed regardless of the correctness of the particular claim concerning Feuerbach. Barth invites us to distinguish, at least conceptually, between the God-talk of a given theological tradition and true Christian theology. Jüngel used later Barthian themes to press a similar distinction between 'the God of the philosophers' or 'traditional dogmatics' and a trinitarian and christological doctrine of God. ${ }^{36}$ In his account of Barth's doctrine of God, Jüngel follows a fairly common nineteenth- and twentieth-century line of suggesting the problem is a hellenistic infection of the God-talk of the early church - this tradition was of course dominant enough in Ritschl to explain Mozley's surprise, noted earlier.

Virtually every major proponent of divine passibility in recent decades has held to an account like this. The doctrine of God found in the Christian tradition - 'traditional dogmatics', in Jüngel's terms - is basically wrong, led into error by importing categories from Greek metaphysics that are incompatible with proper Christian thought about God. ${ }^{37}$ This anti-metaphysical turn has important roots in Baur's, now completely discredited, theory of an early conflict between Petrine and Pauline schools in the early church, ${ }^{38}$ but it has better-placed roots as well, in Ritschl and, particularly, Herrmann.

Assuming that Kant's critical philosophy had in fact destroyed the possibility of metaphysics, and that post-Hegelian Romantic attempts to evade this had in fact failed, Herrmann borrowed gratefully from Schleiermacher the idea that theology is a description of human apprehensions of the divine, and from Ritschl the confidence that critical historical study could reconstruct the normative piety of Jesus of Nazareth, and so dismissed any metaphysical speculation beyond, perhaps, the bare affirmation of the

\footnotetext{
${ }^{35}$ In the 1920 text, unsurprisingly, Barth also notes Feuerbach's usefulness to 'the workers' socialist movement'. 'Ludwig Feuerbach', p. 233.

36 These points tend to be most emphatic when Jüngel is discussing Feuerbach, Nietzsche, and the death of God theologians; see for example “"Deus qualum Paulus creavit, Dei negatio" Zur Denkbarkeit Gottes bei Ludwig Fueuerbach und Friedrich Nietzsche. Eine Beobachtung' Nietzsche-Studien 1 (1972), pp. 286-96. For the point in the major works, see Gott als Geheimnis der Welt (Tübingen: J.C.B. Mohr (Paul Siebeck), 1978), pp. 192-5. On this see John B. Webster, Eberhard Jüngel: An Introduction to His Theology (Cambridge: Cambridge University Press, 1986), p.81, or Colin E. Gunton, 'The Being and Attributes of God: Eberhart Jüngel's dispute with the classical philosophical tradition' in John B. Webster, ed., The Possibilities of Theology: Studies in the theology of Eberhart Jüngel in his sixtieth year (Edinburgh: T\&T Clark, 1994), pp. 7-22. Gunton's own doctoral work had similarly located Barth (and Hartshorne, who has arguably aged less well) as an alternative to a 'classical theism'. Colin E. Gunton, Becoming and Being: The doctrine of God in Charles Hartshorne and Karl Barth (London: SCM Press, 2001²).

37 Alongside works from Jüngel and Gunton already referenced, see for representative example Robert W. Jenson, Systematic Theology vol. 1: The Triune God (Oxford: OUP, 1999), pp. 6-11.

38 For a quick summary of Baur's proposal, and an account of the main lines of critique (which have to do with Baur relying on impossible datings of NT writings) see Stephen Neill and Tom Wright, The Interpretation of the New Testament 1861-1986 (Oxford: OUP, 1988), pp.20-30.
} 
existence of God. ${ }^{39}$ In its place he put an account of the (historically recovered) piety of Jesus as the norm of theology. Herrmann's influence on Barth has been well-charted, particularly (in the anglophone literature) by McCormack.40 On McCormack's telling, Barth continued to accept Herrmann's evaluation of the impossibility of metaphysics, but came to the view that, through divine revelation, we could know far more of God's life than Herrmann ever suspected; as a result, Barth's continued deployment of the traditional vocabulary of technical Christology (e.g.) conceals a fundamental break with the tradition, and a thoroughgoing redefinition of the terms. To take an example from a different essay, McCormack asserts that '... what Barth has done is to dispense with the metaphysical conception of the "person" of Christ altogether. There is no "person" somehow "beneath" the two natures ... The two "natures" - really, divine and human being - are made one in a single human history.' 41

According to McCormack, then, Barth arrives at the same christological position that Weinandy and Congar argue Luther had come to: the 'person' is merely the coming together in history of the two natures. Barth was led to this position through a Kantian rejection of the possibility of metaphysics, mediated by Herrmann, rather than through Luther's eucharistic reflections, but he nonetheless arrives (or at least can be read as arriving) in the same place. It is little surprise, then, to discover Barth's Lutheran disciples - Jüngel supremely, but followed by Jenson and many others - developing doctrines of God that embrace the symmetry of the interchange of attributes, and therefore affirm divine passibility.

Thus far I have merely sought to make good on my opening claim that it has been a commonplace in theology since about 1860 to suggest that Lutheran christology leads naturally, even inevitably, to kenoticism and divine passibility. The argument for kenoticism is more straightforward: Dorner gives us the vital link, accusing his own work, and his arguments has been accepted and repeated both by historians of dogma, and by those interested in developing or criticising kenotic theories. Concerning passibility, I have argued that a development that had little to do with Luther led a significant strand of modern theology to agree with Luther's basic christological position, and from it to develop quickly ideas of divine passibility. In both cases, however, the claim that a Lutheran christology leads quickly to kenoticism and divine passibility are common.

It is worth noting explicitly that these arguments are accepted by supporters (Thomasius; Brown) and opponents (Dorner) of kenoticism, and by supporters (Jenson; Moltmann) and opponents (Weinandy) of divine passibility. Further, my examples have included English, German, French, and American writers, Roman Catholics, Lutherans, Reformed, and Anglicans. The ubiquity and consistency of these arguments is quite remarkable; I will now demonstrate that they are simply wrong.

\footnotetext{
${ }^{39}$ Consider for example, 'Our conceptions of the divine attributes express the way in which faith recognises God's working. We have no right to distinguish from this, as did the older dogmatics, a knowledge of God's nature. The conceptions whereby the older theology proposed to apprehend God's nature are un-Biblical and have no value for faith.' Wilhelm Hermann (tr. Nathaniel Micklem and Kenneth A. Saunders), Systematic Theology (New York: Macmillan, 1927), §37 (p. 97 of the edition cited).

40 Bruce L. McCormack, Karl Barth's Critically Realistic Dialectical Theology: Its genesis and development, 19091936 (Oxford: Clarendon, 1995), pp. 49-68.

${ }^{41}$ Bruce L. McCormack, 'The Person of Christ' in Kelly M. Kapic and Bruce L. McCormack (eds) Mapping Modern Theology: A Thematic and Historical Introduction (Grand Rapids: Baker, 2012), pp. 149-173, p. 171.
} 


\section{Why Lutheran christology does not lead to kenosis or passibility}

By 'Lutheran christology' I do not mean primarily the thought of Martin Luther; I have noted above ambiguities and outright contradictions in Luther's own christological writings, which make it possible to argue that a wide variety of positions are authentic representations of his thought. Rather, I mean the developed scholastic christology of the sixteenth and seventeenth centuries.

My argument is not merely that the scholastic theologians did not teach the genus tapeinoticum, and all that follows from it; that point is generally accepted. Rather, I intend to show that they had solid dogmatic reasons for refusing it, and so were properly immune to the pull of kenosis or passibility. ${ }^{42}$ I further intend to show that (at least some of) their reasons for refusing the genus tapeinoticum have nothing to do with a commitment to impassibility, immutability, or simplicity, but are based firmly in trinitarian and christological dogma.

The history as it is generally told can be summed up with a quotation from McCormack: 'both Reformed and Lutheran theologians identified the genus tapeinoticum as a strictly logical possibility which they rejected. They held that the idea of an ascription of human attributes to God was unthinkable largely as a consequence of their commitment to a concept of divine immutability that was itself controlled by the notion of impassibility.' 43 The hellenistic infection, or improper commitment to metaphysics, was, that is, the only thing that prevented the Lutheran scholastics from teaching a symmetrical interchange of attributes between the natures. Even Schmid's classic summary of the scholastic Lutheran theology gives this same impression: discussing the genus maiestaticum, he notes the following:

there is no reciprocal effect produced; for, while the human nature can become partaker of the idiomata of the divine, and thus acquire an addition to the idiomata essential to itself, the contrary cannot be maintained, because the divine nature in its essence is unchangeable and can suffer no increase. 44 (my italics)

Were one looking for support for this thesis (that hellenistic infection is the reason for denying the genus tapeinoticum) in the scholastics, it would not be hard to find. They certainly believed that the divine essence is unchangeable, and so they were ready to argue in these ways. Gerhard ${ }^{45}$ for example, asserts that 'the deity of the Logos which is

\footnotetext{
42 What follows here is an extensive development of some themes I explored very briefly in an earlier essay: Stephen R. Holmes, 'Radicalising the Communicatio: Jenson's theology in confessional Lutheran perspective' in Stephen J. Wright and Chris E. W. Green (eds) The Promise of Robert W. Jenson's Theology: Constructive Engagements (Minneapolis: Fortress Press, 2017), pp. 131-141.

${ }^{43}$ Bruce L. McCormack, "Divine Impassibility or Simply Divine Constancy? Implications of Karl Barth's Later Christology for Debates over Impassibility," in Divine Impassibility and the Mystery of Human Suffering, ed. James F. Keating and Thomas Joseph White (Grand Rapids: Eerdmans, 2009), pp. 150-186, quotation from p. 175.

${ }^{44}$ Heinrich Schmid (tr. Charles A. Hay), The Doctrinal Theology of the Evangelical Lutheran Church (Philadelphia: United Lutheran Publishing House, 18753) pp. 314-15.

${ }^{45}$ Johann Gerhard (1582-1637), whose massive Loci Theologiae (1610-1621) stands as one of the great works of scholastic Lutheranism. For his life, context, and work, see now Markus Friedrich, Sascha Salatowsky, \&
} 
united with flesh is most pure act, most perfect, and immutable,' ${ }^{\prime 6}$ and Quenstedt ${ }^{47}$ will insist, even more straightforwardly, that the divine nature cannot be the subject of communication because it is 'immutable and cannot be added to' ${ }^{48}$ My claim, then, is not that the scholastics did not make arguments based on immutability, but that they offered other dogmatic reasons to reject the genus tapeinoticum, rooted in their careful accounts of the hypostatic union and the doctrine of the Trinity, which did not rely on any position that might be characterised as an 'hellenistic infection'. Two particular arguments are visible, which I will first state, and then explore in detail.

1. The union of divine and human natures in the person of the incarnate Son was an asymmetrical act, an assumption of human nature by the divine person; the detail of this asymmetry necessarily results in the denial of the genus tapeinoticum.

2. Human nature and divine nature are different things, which is a necessary result of the doctrine of the Trinity. The detail of this difference leads both to the affirmation of the genus maiestaticum and the denial of the genus tapeinoticum.

The first point is already visible in Brenz, ${ }^{49}$ writing only a few years after Luther's death. He states (in a phrase quoted approvingly by Jenson), '[a]lthough it is a property only of the divine nature in Christ to be everywhere and fill all things, nevertheless he possesses this property only in common with his human nature, that he assumed into the one and same person that he is. ${ }^{\prime 50}$ Brenz makes nothing of the asymmetry here, but carefully indicates it: the divine Logos actively assumes human nature into personal subsistence with himself; the humanity is passively assumed. Brenz, that is, gestures towards the anhypostatic origin of the human nature (and implicitly towards the enhypostatic existence of the human nature: the one person, fully divine and fully human, who the

Luise Schorn-Schütte (heraus.) Konfession, Politik, und Gelehrsamkeit. Der Jenaer Theologe Johann Gerhard (1582 - 1637) im Kontext seiner Zeit (Stuttgart: Franz Steiner Verlag, 2017).

46 'Deitas Logou carni unita est purissimus actus, est perfectissima et immutabilis...' Johann Gerhard, Loci Theologie (ed. Preuss) IX vols; vol. I (Berlin: Gustav Schlawitz, 1864) iv.257 (p. 576 of edition cited).

47 J. A. Quenstedt (1617-1688): Gerhard's nephew, his Theologia Didactico-Polemica (1685) is arguably the most scholastic of all Lutheran theological texts, in both the best and worst senses of that term. There appears to be little recent secondary literature, unfortunately; Michael Coors, Scriptura efficax. Die biblisch-dogmatische Grundlegung des theologischen Systems bei Johann Andreas Quenstedt. Ein dogmatischer Beitrag zu Theorie und Auslegung des biblischen Kanons als Heiliger Schrift (Forschungen zur systematischen und ökumenischen Theologie, Bd 123) (Göttingen: Vandenhoeck \& Ruprecht, 2009) is useful on the shape and (particularly) the Scriptureprinciple of Quenstedt's theology, but offers little explicitly on his christology; there is a brief but interesting treatment of Trinitarian theology (pp. 232-239), which however does not engage with the themes I am developing here.

48 'Subjectum Quo est Natura, ad quam facta est communicatio. Est vero illa non divina, utpote cui ob summam immutabilitatem nihil addi potest.' Johanne Andrea Quenstedt Theologia Didactico-Polemica, sive Systema Theologicum... (Lipsiae (sic, 'Leipzig'): Thomas Fritsch, 1715), III.75 (col. 144 of the edition cited). 49 Johannes Brenz (1499-1570) was present at the Heidelberg Disputation (1518), and became committed to the cause of Reform on hearing Luther there. He was a major administrative leader of early Lutheranism, whose writings on church order were influential into the twentieth century; his other great contribution was a polemical defence of Lutheran Eucharistic theology, focussing on the question of the genus maiestaticum, De personali unionem duarum naturarum in Christo (1561). For a full account of Brenz's Christology see Hans Christian Brandy, Die späte Christologie des Johannes Brenz (Tübingen: Mohr/Siebeck, 1991). He deals with this point concerning asymmetry on pp. 193-4.

50 'Quare etsi solius diuinae naturae in Christo properietas est, ubique esse \& omnia implere, tamen habet hanc proprietatem communem, cum sua humanitate, quam in eandem personam assumpsit.' Johannes Brenz, De personali unione duarum naturam in Christo (Tübingen, 1561), p. 11; translation from Jenson, ST, I.203. 
mediator is, is the Second Person of the Trinity). Of itself, this proves nothing, ${ }^{51}$ but later dogmaticians made it do considerable work; I consider Gerhard and Quenstedt.

Gerhard's eleventh proposed objection to the genus maiestaticum turns on reciprocity, and addresses precisely the argument I am considering in this essay: if the communicatio is reciprocal, then we would have to ascribe mortality to the divine nature just as we ascribe omnipotence to the human nature. But (Gerhard thinks) that is obviously absurd, so we need to demonstrate that there in asymmetry, not reciprocity, in the communicatio. ${ }^{52}$ Gerhard distinguishes between the genus idiomaticum, which he accepts is reciprocal, and the genus maiestaticum, which he insists is not. Why so? Because although the union is symmetrical with regard to natures, the 'condition of the natures in the union is not equal.' 53 Gerhard goes on to make explicitly the point that Brenz made carefully but silently: 'The Logos is the assuming person, the human nature is assumed.' 54 Since, he argues, the human nature is assumed into the hypostasis of the Logos, the natural properties of the Logos are communicated to the human nature; the human nature, being assumed, receives but does not give in this exchange of properties. In being assumed into a divine person, the human nature is made capacious of the divine perfections, and so the genus maiestaticum obtains; the divine nature is never assumed into a human person, and so the genus tapeinoticum does not.

Quenstedt makes the same argument again, when he discusses the enhypostatic existence of the human nature in one of the polemical sections of his Theologia Didacto-Polemica. ${ }^{55} \mathrm{He}$ responds to an argument (which he attributes to the Calvinists in general, and particularly to Joseph Grabius) that the human nature remains anhypostatic. Quenstedt clearly believes (and implies that his opponents believe) that if he can once prove the enhypostasia, the assumption of the human nature into the person of the Logos, such that the human nature has its hypostatic existence in the person of the Logos, then the genus maiestaticum will inevitably follow. ${ }^{56}$ He repeatedly insists that the asymmetry of the act of assumption means that there need be no symmetry concerning the communication of attributes. The person of the Logos assumes the human nature into subsistence with himself, and so the human nature is taken up into the majesty of the Logos; there is no reciprocal action. His polemical purpose in this section means the theme constantly reappears in different ways. It is already present in the thesis statement: 'He has the divine nature of the Logos first and of himself, the human nature second and of another.'57

The scholastic care of Quenstedt's argument is remarkable. Faced at one point with the objection (which he identifies as 'Calvinist') that the human nature cannot have any hypostatic existence, since anything that has hypostatic existence is a person, and the

\footnotetext{
${ }^{51}$ A point on which I was in error in my 'Radicalising the communicatio...' essay.

52 This is a restatement of the italicised argument at the beginning of Gerhard, Loci, iv.257 (p. 576 of the edition cited).

53 'Quamvis enim unio naturarum sit aequalis et reciproca, tamen conditio naturarum unitarum non est aequalis.' Gerhard, Loci, iv.257 (p. 576).

54 'Logos est persona assumens, humana natura assumitur.' Gerhard, Loci, iv.257 (p. 576).

${ }_{55}$ Quenstedt, Theologia... III.ii Q.IV (cols 190-198).

56 See, e.g., III.ii Q.IV Antithesis IV (col. 193).

57 'Logos... divina natura logou iam habeat protos et kat' auto, humana vero deuteros et kat' allo...' Quenstedt, Theologie... III.ii Q.IV Thesis (col. 190).
} 
human nature is not a person, he responds by claiming ambiguity in the term 'hypostatic existence' and forcing a distinction, essentially creating space for enhypostatic existence. 58

When he turns explicitly to the communcatio idiomatum in his polemics, ${ }^{59}$ he works methodically, first discussing the idea in general, then the genus maiestaticum, and then enumerating several divine perfections which are (he believes) communicated under it, and defending their communication one by one. His very first observation following his thesis statement on the genus maiestaticum is all about asymmetry:

Reciprocity, which has a place in the first genus, does not occur in this genus of the communicatio idiomatum: for although it is appropriate for the human nature to be advanced or exalted, it is not possible for the divine nature to be humiliated [tapeinosis], emptied [kenosis] or lessened ... The assumed nature is promoted, not the assuming one. ${ }^{60}$

Here we see the immutability argument that McCormack identified, to be sure; we also see however the asymmetry argument in the final line. As we move on through his arguments, it is clear that asymmetry is what is crucial to him. Responding to Calvinist claims that divine simplicity makes the genus maiestaticum impossible, Quenstedt first offers a series of exegetical arguments proving the possibility of communication of divine perfections, but then leans on the distinction between communication of the divine essence, which he agrees is impossible, and communication from the divine person, which he wishes to assert. ${ }^{61}$ Note that the possibility of the genus tapeinoticum is not in view here, but the arguments advanced serve to refute it anyway; he is developing an asymmetrical account of the incarnation, which event therefore, on his account, has radically different consequences for the divine and human natures.

Later he does face the possibility of reciprocity. He is pressed (he states) by Calvinists and Jesuits, in the mouth of which unlikely alliance he puts the following argument: 'If, because of the perichoretic nature of the personal union, the divine nature communicates its properties to the human, then so must the human nature contribute its properties to the divine...' Quenstedt's response is straightforward: 'There is no reciprocal equality in the union of natures' ${ }^{62}$ The divine nature unites; the human nature is assumed; the person of the Logos does the assuming. A battery of citations follow, from Leo, Athanasius, and Augustine.

Baier makes the same point, albeit in slightly different terms. ${ }^{63}$ Because of the asymmetry in the act of assumption, he suggests that 'the divine nature inwardly penetrates and

\footnotetext{
${ }^{58}$ Quenstedt, Theologia... III.ii. Q.IV Obj. iv (col. 196).

${ }^{59}$ Quenstedt, Theologica..., III.ii QQ.IX-XIV (col. 222-285)

60 `Reciprocatio, quad in primo genere locum habet, in hoc genere Communcationis Idiomatum secondum non datur: Neque enim uti fit naturae humanae beltiosis sive huperupsosis, ita etiam naturae divinae tapeinosis, kenosis, elatiosis fieri potest ... Assumpti provectio est, non assumentis.' Quenstedt, Theologica... III.ii. Q.X Ekth. I (col. 228).

${ }^{61}$ Quenstedt, Theologica... III.ii Q.X Obj. 2.

${ }^{62}$ 'Si propter unionem personalem et naturarum perichoresin natura divina comunicat idiomata sua humanae, propter eandem etiam humana natura communicabit idiomata sua divinae'; 'Resp. Non pariter reciproca est unio respectu utriusque naturae.' Quenstedt, Theologia...III.ii Q.X obj. iix (col.237-238). ${ }^{63}$ Johann Wilhelm Baier (1647-1695) is chiefly remembered for his Compendium Theologiae Positivae, which, as the title suggests, is largely a drawing together of the teachings of earlier Lutheran theologians.
} 
perfects the human; but the human does not in turn penetrate or perfect the divine.' 64 Given the dogmatically-proper use of 'perichoresis' to describe the hypostatic union, I am not sure that this is the happiest way of phrasing the distinction, but it is further evidence that the point I am developing concerning asymmetry is simply central to scholastic Lutheran christology. Many other examples could be adduced.

From all this evidence it should be clear both that the Lutheran scholastics were energetic in insisting on an asymmetry in the act of hypostatic union, and that they believed that this asymmetry allowed them to affirm the genus maiestaticum whilst denying the genus tapeinoticum. How far does this argument work? Certainly the proposed asymmetry allows them to deny that the one must necessarily lead to the other: the argument from reciprocity fails, because there is no reciprocity. They seem to want to go further, however, and suggest that the personal assumption of the human nature by the Logos is itself adequate to establish the genus maiestaticum. This is a surprising argument, since personal assumption is ecumenical orthodoxy, and has been since Chalcedon, and yet the genus maiestaticum is a Lutheran distinctive. The argument would seem to rely on a particular account of how properties adhere to natures, which must go something like this: natures are abstractions that describe clusters of properties which identify kinds: to be divine is to be omnipotent, omniscient, etc., and 'divine nature' is an abstract term we use to denote this cluster of properties. Persons are actually existent things (hypostases), and so are actually possessed of properties. The nature that is instantiated in a particular person, therefore, must be possessed of all the properties which that particular person is possessed of.

The person of the incarnate Logos is possessed of both human and divine properties, and so the nature instantiated in the person must also be so possessed. Therefore (as we saw Quenstedt claiming above), the establishment of the enhypostasia is enough to prove the genus maiestaticum. I assume that his reasoning looked something like the argument I have just sketched, although unfortunately he does not pause to explain it to us. However, this particular account of natures as abstractions is very reminiscent of the work of another leading Lutheran dogmatician, Martin Chemnitz, who preceded Quenstedt and so can be presumed to have influenced him. ${ }^{65}$

The argument I have stated works, but it is also fatally flawed for my purposes: it is symmetrical; it proves the genus tapeinoticum just as effectively as it proves the genus maiestaticum. Chemnitz, however, had already seen that, and provided a response. He begins De Duabus Naturis by defining his terms: 'nature' is 'something common to the

\footnotetext{
64 '...divina natura humanam intime pentrat et perficit; humana vero non vicissim penetrat ac perficit divinam.' Johann Wilhelm Baier (curavit E. Preuss), Compendium Theologiae Positivae (Berolini [sic, Berlin]: Sclawitz, 1864).

${ }^{65}$ Martin Chemnitz (1522-1586) is frequently ascribed the pre-eminent place amongst Lutheran dogmaticians, after Luther himself, and for that reason sometimes styled 'the second Martin'. His commentary on the Council of Trent is one of the great defences of Protestantism, and he wrote three books on the Eucharistic controversy, of which one, De Duabus Naturis in Christo, focused exclusively on the christological problems. J.P.H. Preuss, The Second Martin: The Life and Theology of Martin Chemnitz (St Louis: Concordia, 1994) is perhaps a little popular in tone, but offers an easy introduction for Anglophone readers; Hendrick Klinge, Verheißene Gegenwart: Die Christologie des Martin Chemnitz (Göttingen: Vandenhoeck \& Ruprecht, 2015) is the most recent scholarly treatment of his Christology.
} 
many individual members of the same species.' 66 Almost immediately, however, he introduces the crucial asymmetry: '[w]e must note, as Damascenus points out in De Fide Orthodoxa I.8, that in creatures the nature common to each does not subsist in itself...'67 'Humanity', that is, is an abstraction, it exists only in that particular humans exist, and share certain properties. Chemnitz, that is, states the definitions that I have argued must have been in place for the Lutheran argument I was tracing to work.

He then, however, introduces a crucial distinction, already hinted at in the phrase 'in creatures' in the citation from John of Damascus. '[I]n the case of the deity, its common nature of essence is not something imaginary or only an abstract thought or something which only appears to be one, but it actually is the one and undivided deity, which, however, is communicable and is common to the Three Persons.' ${ }^{68}$

The point is a basic one, predicated on standard trinitarian orthodoxy: the unity of the divine nature is a reality (indeed, possibly 'Reality itself'), not an abstraction. The three Persons are truly and really and actually one God. He goes on to explain this point at careful length:

The divine essence is predicated of the Father, of the Son, and of the Holy Ghost, not as a genus is predicated of a species, or as a species is predicated of an individual, or as a whole of its parts, but in an entirely ineffable and incomprehensible way the hypostases or persons of the Trinity are all one because of the identity of essence. Hence they do not differ in essence, nor do they subsist separately, one outside the other, or one without the other. 'For the Father is in Me and I in the Father,' says the Son (John 10:38). ${ }^{69}$

Every creaturely nature, that is, is, according to Chemnitz, merely an abstraction, but the divine nature exists as the unity of the Godhead. This is a different asymmetry to the one I have previously explored, but it helps Chemnitz to do much of the same work. (Chemnitz is happy to employ the other asymmetry as well. ${ }^{70}$ )

Chemnitz's initial definition of 'person' is straightforward: 'an individual, intelligent, incommunicable substance which is not part of something else, is not sustained by something else, and does not depend on something else. ${ }^{\prime} 11$ He makes the necessary move I identified above, however, in his defence of the genus maiestaticum, where he objects to the 'sophistry' of asserting that the divine perfections were communicated only to the person, not to the human nature, by asserting that there is no referent for the word 'person' except the union of the natures: 'the person of Christ consists of the two natures which make up the one unique person of Christ' ${ }^{72}$ (Note that this is precisely the position McCormack claimed Barth arrived at, that, he claimed, invited Barth's followers to assert the genus tapeinoticum and divine passibility.)

\footnotetext{
${ }^{66}$ Martin Chemnitz De Duabus Naturis in Christo... (Lipsiae [sic Leipzig]: no press stated, 1580), p.7; ET from Chemnitz (tr. J.A.O. Preuss), The Two Natures in Christ (St Louis: Concordia, 1971), p. 29.

${ }^{67}$ Chemnitz, De Duabus p. 8; Two Natures, p. 30.

${ }^{68}$ Chemnitz, De Duabus, p. 8 Two Natures, p. 30.

${ }^{69}$ Chemnitz, De Duabus, p. 8 Two Natures, p. 30.

70 '...the divine nature in the person of the Son has assumed the human nature...' Chemnitz, De Duabus p. 9;

Two Natures p. 31; this is actually part of a quotation from Lombard, Sent. 4.27.

${ }^{7}$ Chemnitz, De Duabus, pp. 7-8; Two Natures, p. 29.

72 Chemnitz, De Duabus, p. 298; Two Natures, p. 283.
} 
Chemnitz's account of the hypostatic union affirms this point, and also displays the asymmetry that I have been stressing: 'the hypostatic union is the highest and most intimate coming together by which the divine nature assumes and the human nature is assumed and made the property of the divine, so that these two natures ... are united to produce one person in Christ.' ${ }^{73}$ In explanation, he will immediately however make a further distinction: 'the person of the Son of God, subsisting from eternity in the divine nature, assumed in fullness of time a particular individual unit (massa) of human nature, so that in Christ the assuming nature is the divine, and the assumed nature is the human. ${ }^{74}$ Because of this, and because of the individuation possible in created natures, the particular human nature assumed subsists only in the person of the Logos, and is made a 'property' of the Logos. On the basis of this, Chemnitz argues, 'Christ's divine nature did not pertain only to the completeness of the person of the incarnate Christ, but at the same time also pertained to the assumed human nature. ${ }^{\prime 75}$ On this account, he asserts the genus maiestaticum and denies the genus tapeinoticum, insisting that both the assertion and the denial are the result of the assumption of the human nature into the person of the Logos. ${ }^{76}$

I cannot find Quenstedt stating the same definitions of 'person' and 'nature' as Chemnitz advances, but he regularly cites Chemnitz, and his logic, as sketched above, seems to rely on Chemnitz's definitions, so I think we may accept that he uses at least very similar conceptions. There is, then, a sense in which my first and second numbered arguments above are similar, but Quenstedt's focus on the asymmetry and Chemnitz's on the nature of natures seem sufficiently different to make them different arguments.

So, we have an argument from christology and an argument from trinitarian doctrine. The writers cited had many other arguments for the genus maiestaticum, of course: Chemnitz in particular offers an essentially exegetical defence of the doctrine, with a massive collation of Biblical texts and citations of ancient authors being far more important to his account than the narrow logical distinctions I am exploring here. My point has been to show that, even absent any belief in divine immutability and/or impassibility, the Lutheran Orthodox had adequate dogmatic resources to refuse any suggestion of a symmetry or reciprocity between the genus maiestaticum and the genus tapeinoticum. They understood the incarnation to be an essentially asymmetric assumption of human nature by the divine person of the Logos; that asymmetry, they believed, meant that the communication of attributes between the natures happened in one direction but not in another. On this basis, the widespread historical thesis I explored in the first section of this essay is demonstrably wrong: Lutheran christology does not imply kenosis or divine passibility.

\section{Suffering and 'classical theism': Implications for contemporary theology}

It is tempting to ask if any of this matters; the era of the schools is long over, and the precise details of why they affirmed what they affirmed and denied what they denied are at most of minor historical interest. Such a hasty dismissal would be a mistake, however.

\footnotetext{
73 Chemnitz, De Duabus, p. 53; Two Natures, p. 69.

74 Chemnitz, De Duabus, p. 63; Two Natures, p. 76.

75 Chemnitz, De Duabus, p. 66; Two Natures, p. 78.

76 Chemnitz, De Duabus, p. 73.
} 
The argument I have offered speaks directly to two key discussions in contemporary dogmatics: the problem of suffering, and the rejection of 'classical theism'.

Negotiating human suffering is in many ways the decisive issue of modern dogmatics. One way or another, almost every significant proposal orbits around this issue. I referenced two writers above who claimed that the idea of divine passibility had become almost universal in academic theology in the 1980s; it is fair to say that this hegemony has not quite been maintained, perhaps as a result of some weighty critiques; ${ }^{77}$ nonetheless, two demands that drove it are still generally perceived as urgent. One concerns divine love: even if God does not suffer, we must be able to give some meaningful content to the concept of divine benevolence. The other concerns God's engagement with human suffering: even if God does not suffer, we must be able to give some account of how God knows our suffering.

My arguments in this paper offer a response to the second point: the asymmetrical account of incarnation I have found in the Lutheran Orthodox allows the affirmation that the genuine human suffering of the Incarnate One is both known by God, and known by God to be the personal experience of the Divine Son, without however invoking an account of divine passibility. The sixth-century theopaschite formula, 'one of the trinity suffered in the flesh', already pointed in this direction ${ }^{78}$ (although the controversy then was far more about the inseparability of divine operations than suffering; accounts of the impassible suffering of the incarnate Son had been common since at least Cyril of Alexandria ${ }^{79}$ ). Contemporary references to patristic ideas of impassible suffering tend to be impatient, suggesting that logical incoherence was accepted because of an alien commitment to divine impassibility; the scholastic account of the incarnation I have been tracing in this essay, however, demonstrates that it is possible to hold to these patristic ideas without any incoherence, and so offers a significant alternative option to a central contemporary debate.

Turning to classical theism, I noted above that an account of the older doctrine of Godthe doctrine of the Lutheran scholastics, amongst others - as inadequate because of metaphysical infection is routinely assumed in recent systematic theology. As I have explored, this can be traced back to Baur and Herrmann in different ways, but in much contemporary systematic theology it functions as an axiom, an unexamined assumption which is quickly stated without any apology or defence because it is seemingly beyond question. Doctrines of simplicity, immutability, impassibility, and so on, are seen as endemic and hardy weeds that the contemporary systematician must pull out from amongst the good plants, in the hope that something of use or at least ornament will be left once the operation is complete.

It is remarkable just how pervasive and strident this assumption is. Barth (who however does better than most here in my estimation) speaks of simplicity as 'exalted to the all-

\footnotetext{
77 See particularly Thomas G. Weinandy, Does God Suffer? (Notre Dame: University of Notre Dame Press, 2000).

${ }^{78}$ For an overview of the theopaschite controversy, see Patrick T. R. Gray, The Defense of Chalcedon in the East, 451-553 (Leiden: Brill, 1979), 451-553.

79 See J. Warren Smith, “Suffering Impassibly: Christ's Passion in Cyril of Alexandria's Soteriology," ProEccl 11 (2002): 463-83.
} 
controlling principle, the idol ... devouring everything concrete...' ${ }^{80}$ My own Doktorvater, Colin Gunton asserted, '[i]t is one of the tragedies - one could almost say crimes - of Christian theological history that the Old Testament was effectively displaced by Greek philosophy as the theological basis for the doctrine of God...' ${ }^{81}$ We have met already Jenson, Jüngel, Fiddes and Moltmann telling a similar story, but the language here is astonishingly strong: 'idol'; 'tragedy'; 'crime'. The sense of a basic betrayal, a catastrophic error, is difficult to escape.

Of course, the writers named above belong to a particular strand of contemporary systematics, being protestant and Barthian (whatever that epithet means). The claim goes much wider, however. It can be found in feminist theology, ${ }^{82}$ open theism, ${ }^{83}$ even the death of God theologies. ${ }^{84}$ A recent survey of confessionally Evangelical doctrines of God suggested that virtually everything currently written in that confessional tradition is negotiating this question somehow. ${ }^{85}$ Further, this theme is deployed as something assumed and unquestioned in serious readings of historical figures. ${ }^{86}$ It is hard not to regard it as ubiquitous in contemporary protestant theology. ${ }^{87}$

There have already been challenges to such ideas, and weighty ones at that. Some focus on a particular thinker, arguing that he (almost always...) is not guilty of the general charge of a surrender to alien metaphysics. Several recent treatments of Aquinas, for example, have taken this line. ${ }^{88}$ Others focus on one or another of the disputed doctrines, arguing that it is not as unbiblical as suggested. ${ }^{89}$ This is all, however, in danger of being piecemeal, in that individual thinkers and concepts are being addressed. Over time, the broader historical consensus might suffer a 'death of a thousand cuts' but the very presence of so many excellent push-backs, and their rather limited efficacy, combine to suggest that we might be waiting some time.

\footnotetext{
80 C.D. II/1, p. 329.

${ }^{81}$ Colin E. Gunton, Act and Being: Towards a Theology of the Divine Attributes (London: SCM Press, 2002$)$, p. 3.

82 See, e.g., Rosemary Radford Ruether, 'The Liberation of Christology from Patriarchy', in Ann Loades (ed.), Feminist Theology: a Reader (London: SPCK, 1990), pp. 138-148.

83 See, e.g., Clark Pinnock, et al., The Openness of God: A Biblical challenge to the traditional understanding...

(Downers Grove, IL: IVP, 1994), p. 106.

84 Thomas J.J. Altizer, The Apocalyptic Trinity (New York: Palgrave Macmillan, 2012), p. 61.

${ }^{85}$ Kevin J. Vanhoozer, 'The Triune God of the Gospel' in Timothy Larsen and Daniel J. Trier (eds) The

Cambridge Companion to Evangelical Theology (Cambridge: CUP, 2007), pp. 17-34; see particularly pp. 19-20

(for the definition of 'classical theism') and pp. 22-28 for the judgement that negotiating this is central.

${ }^{86}$ For example, Sang Hyun Lee, The Philosophical Theology of Jonathan Edwards (Princeton: Princeton

University Press, 1988), see the thesis statements on pp. 3-4 for an indication of just how central the assumed critique of 'classical theism' is to the account.

87 Breidert offers a similarly broad judgement at the beginning of his monograph, referencing Altizer, Moltmann and von Balthasar in particular. Die kenotische Christologie... p. 13.

88 To offer only three examples, Giles Emery (tr. Francesca Ann Murphy), The Trinitarian Theology of St Thomas Aquinas (Oxford: OUP, 2007) offers a careful restatement of Thomas without controversy; Matthew Levering, Scripture and Metaphysics: Aquinas and the Renewal of Trinitarian Theology (Oxford: Blackwell, 2004) brings Thomas into direct conversation with the sort of revisionary proposals I have been considering, as does D. Stephen Long, The Perfectly Simple Triune God: Aquinas and his Legacy (Minneapolis: Fortress Press, 2016).

${ }^{89}$ For example, on simplicity: Jordan P. Barrett, Divine Simplicity: A Biblical and Trinitarian Account (Minneapolis: Fortress Press, 2017) and James E. Dolezal, God without Parts: Divine Simplicity and the Metaphysics of God's Absoluteness (Eugene, OR: Pickwick, 2011); on impassibility Weinandy, Does God Suffer?.
} 
By focusing on Lutheran christology, I hope to have short-circuited some of these discussions. As I argued in the first section, a purported result of Lutheran christology, divine passibility, is held up repeatedly as the great result of removing Greek metaphysics from Christian doctrine. But I have shown that this fails completely: I have allowed, for the sake of argument, that such ideas as immutability, impassibility, or eternity are merely Greek accretions, and have no place in a Christian doctrine of God; I have demonstrated that even under such strictures, the Lutheran schoolmen had compelling reasons for assuming that the adoption of the genus maiestaticum does not give any reason to adopt the genus tapeinoticum. Rather, the resistance to the latter stems from the straightforward deployment of ecumenical dogma concerning the hypostatic union and the Trinity.

I return to Eberhard Jüngel, surely one of the most intellectually able theologians of the second half of the twentieth century. Jüngel assumed and asserted that we needed to set 'a trintarian and christological' doctrine of God against the 'traditional dogmatics' that was characterised by a denial of divine passibility. I have argued that, in Jüngel's own tradition, the denial of divine passibility was precisely the result of holding to 'a trinitarian and christological doctrine of God.' If this is right, then the basis of Jüngel's argument is simply undermined. He, and those who would travel a similar road to him (which, as I have suggested, can seem to be almost everybody in contemporary protestant dogmatics), have no place to stand. The remarkably widespread dogmatic appeal of the last sixteen decades or so to a supposed authentic Lutheranism as a justification for a kenotic christology, an account of divine passibility, and even a novel doctrine of God, just fails. It has no validity. The edifices, admittedly impressive, that are built upon it, are built on sand. ${ }^{90}$

${ }^{90}$ I am very grateful to my colleagues Prof. Judith Wolfe and Dr Bill Tooman for their helpful comments on an earlier draft of this paper. 